\title{
Tarihi Fil Köprüsü’nün yapısal ve dinamik özelliklerinin incelenmesi
}

\author{
Investigation of the structural and dynamic properties of Historical Fil Bridge
}

\author{
Muammer ÖZBEK*1,a, Sıddık ŞENER ${ }^{2, b}$ \\ ${ }^{1}$ İstanbul Bilgi Üniversitesi, Mühendislik ve Doğa Bilimleri Fakültesi, İņ̧aat Mühendisliği Bölümü, 34060, İstanbul \\ 2 Ístanbul Beykent Üniversitesi, İnşaat Mühendisliği Bölümü, 34398, İstanbul
}

• Geliş tarihi / Received: 04.05.2020 • Düzeltilerek geliş tarihi / Received in revised form: 08.11.2020 • Kabul tarihi / Accepted: 17.11.2020

\begin{abstract}
$\ddot{O} z$
Bu çalışmada, 1932 yılında İstanbul ili, Eyüpsultan ilçesinde, Alibeyköy Deresi üzerine inşa edilen ve 2018 yılında kontrollü bir şekilde yıkılana kadar 86 yıl boyunca hizmet veren tarihi Fil Köprüsü'nün yapısal ve dinamik özellikleri incelenmiş ve kayıt altına alınmaya çalışılmıştır. Bu amaçla, yerinde alınan ölçümlerle, köprünün rölevesi çıkarılmış, hasarsız test metotları kullanılarak malzeme özellikleri belirlenmiştir. Elde edilen bilgiler ışığında köprü, SAP2000 programı kullanılarak modellenmiş, dinamik özellikleri (titreşim periyotları ve mod şekilleri) hesaplanmıştır. Bilgisayar modeli yardımıyla bulunan bu sonuçlar, yapı üzerinde alınan serbest titreşim ölçümlerinden hesaplanan titreşim periyotlarıyla da karşılaştırılmıştır.
\end{abstract}

Anahtar kelimeler: Betonarme kemer köprüler, Hasarsız malzeme testleri, Sistem tanımlama, Titreşim ölçümü, Yapısal analiz

\begin{abstract}
In this work, the structural and dynamic characteristics of the historic Fil (Elephant) Bridge, which was built on the Alibeyköy Creek in Eyupsultan district of Istanbul in 1932 and served for 86 years until it was demolished in 2018, were investigated. For this purpose, the structural layout plans of the bridge were re-produced by on-site measurements and material properties were determined by non-destructive test methods. In the light of the obtained information, the bridge was modeled by using SAP2000 Structural Analysis Program and the dynamic characteristics such as vibration periods and mode shapes were calculated. The modal parameters obtained from SAP2000 model were then compared with those extracted from the vibration measurements taken on the structure.
\end{abstract}

Keywords: Reinforced concrete arch bridges, Non-destructive material testing, System identification, Vibration measurement, Structural analysis

\footnotetext{
*a Muammer ÖZBEK; muammer.ozbek@bilgi.edu.tr, Tel: (0212) 311 74 64, orcid.org/0000-0002-1161-0512

${ }^{\mathrm{b}}$ orcid.org/0000-0001-6659-5367
} 


\section{Giriş}

Fil Köprüsü, İstanbul ili, Eyüpsultan ilçesi sınırları içinde, Haliç'in sonunda Alibeyköy Deresi üzerine inşa edilmiştir. Tek açıklıklı betonarme kemer şeklinde tasarlanan köprü, görünüm olarak file benzetilmesi sebebiyle bu isimle anilırken, yapıldığ 1 bölgeye de adını veren Silahtar Mehmet Ağa sebebiyle Silahtarağa Köprüsü olarak da adlandırılır (Șener ve Şener, 2015). Bu bölge aynı zamanda İstanbul'un ilk elektrik santrali olarak 1911 yllında Sultan II. Abdulhamid döneminde kurulan Silahtarağa Termik Santraline de ev sahipliği yapmaktadır.

Köprü, termik santral çalışanlarının Eyüp bölgesine ulaşımlarını kolaylaştırmak amacıyla yapılmıştır. 1930 yılı Ağustos ayında başlayan inşaat, 122,917 Türk Lirası bedelle, 1932 yılında tamamlanmıştır. Silahtarağa Termik Santrali'nin 1983 y1lında faaliyetine son vermesini takiben, santralin üzerinde kurulu olduğu alan 2004 yılında İstanbul Bilgi Üniversitesi'ne tahsis edilmiştir. Köprü bu tarihten itibaren 2018 y1lında yol genişletme çalışmaları sebebiyle yıkılana kadar üniversite öğrencileri ve bölge sakinleri tarafından yoğun olarak kullanılmıştır.

Fil Köprüsü, üniversite kampüsüne çok yakın olması sebebiyle yazarların dikkatini çekmiş, önemli bir tarihi değere sahip olduğu anlaşılınca da henüz hizmette iken yapının özellikleri, bir ön çalışma ile belgelenmeye ve kayıt altına alınmaya çalışılmıştır. Bu makalede ise daha önce bir bildiri şeklinde sunulan bu ön çalışmamızın (Şener ve Şener, 2015) kapsamı, bir bütünlük oluşturacak şekilde;

- köprü üzerinde yapılan detaylı malzeme testleri,

- dinamik serbest titreşim ölçümleri,

- operasyonel modal analiz metotlarıyla çıkarılan dinamik özellikler ve

- yapının SAP2000 programı kullanılarak oluşturulmuş 3 boyutlu modelinin analizinden elde edilen sonuçların da eklenmesiyle önemli ölçüde genişletilmiştir.

Yapı, tek açıklıklı betonarme kemer köprü olarak tasarlanmıştır. Yapısal sistemi oluşturan bileşenler başlıca 4 kısımda incelenebilir. $\mathrm{Bu}$ bileşenler sırasıyla; kemer şeklinde 2 adet üst başlık, üzerinden trafik akışı sağlanan alt başlık, alt ve üst başlıkları birbirine bağlayan 2 sıra halinde toplam 24 adet düşey askı çubukları ve kemerlerin yanal yüklemelere karşı birlikte çalışmasını sağlayan ve yanal burkulmaları önleyen 4 adet enine yatay kiriş (rüzgar kirişi) olarak sıralanabilir. Köprünün her iki ucunda aydınlatma amacıyla kullanılan $2.7 \mathrm{~m}$ uzunlukta $0.7 \mathrm{~m}^{2}$ kesitli kuleler mevcuttur. Köprünün yıkılmadan önce henüz hizmetteyken çekilmiş bir fotoğrafı aşağıda Şekil 1'de görülebilir.

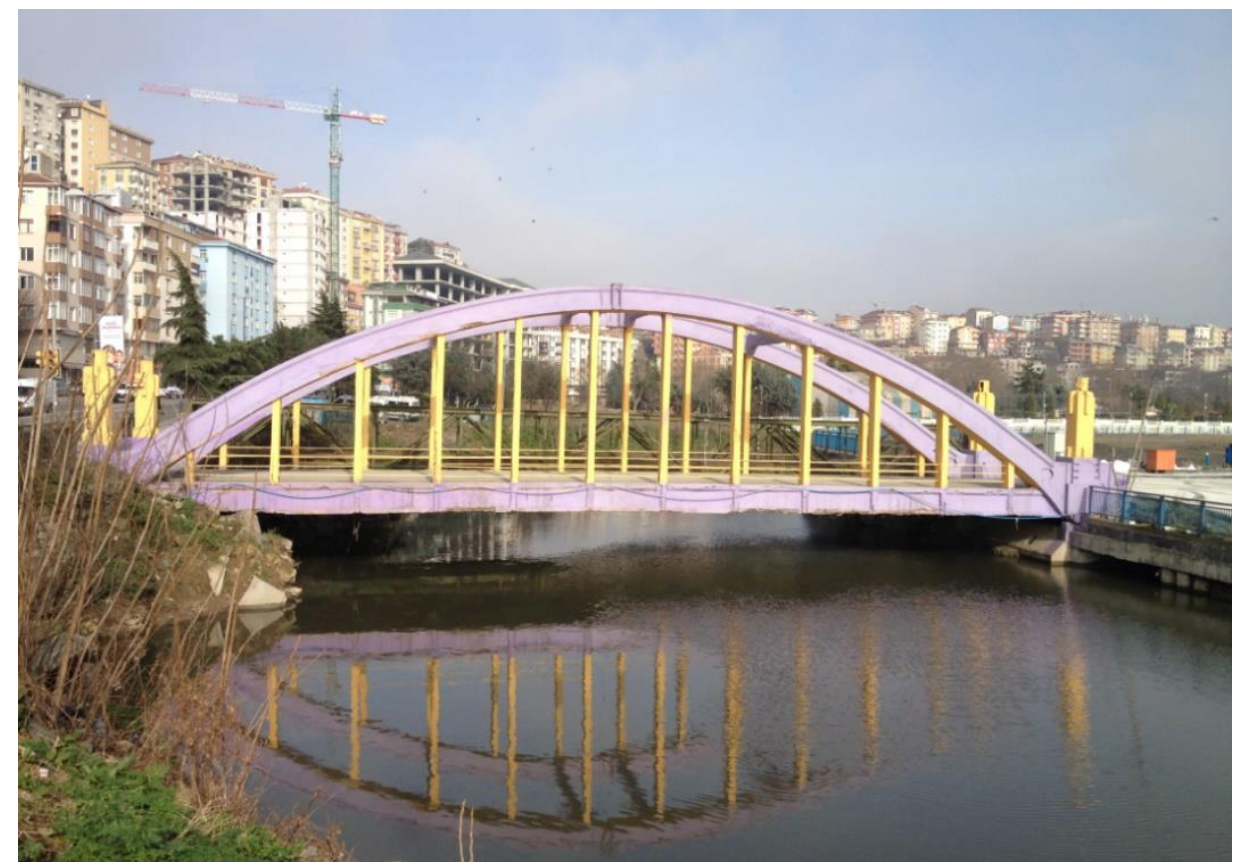

Şekil 1. Fil Köprüsü

Köprü döşemesinin alt yüzü su yüzeyinden yaklaşık 1.5 metre yüksektedir. Bu özelliği sebebiyle dere seviyesindeki yükselmelerden ve taşkınlardan etkilenmeden üzerinden ulaşım güvenle sağlanabilmiştir. Köprü kenar ayakları sağlam zemine ahşap kazıklar (KGM, 2012) 
yardımı ile oturtulmuştur. Alibeyköy deresi geçmişte uzun y1llar boyunca yeterli arıtma tesislerine sahip olmadan atık suyun deşarjı amacıyla kullanıldığından dere yatağı Haliç gibi kalın çamur tabakası ile kaplıdır. Zemin koşullarının bu elverişsizliği köprü yakınlarındaki Silahtarağa Elektrik Santrali inşaatı sırasında saptanmıştır. Bu nedenle zemini daha iyi tanımak için ek sondajlar yapılmış ve $23 \mathrm{~m}$ boyunda ahşap kazıklarla testler yapılarak zayıf zeminin $20 \mathrm{~m}$ gibi bir derinliğe kadar indiği görülmüştür. Bu yüzden köprü kazıklarının uzun olması ve kazık yüklerinin sınırlı bir değerde tutulması gerektiği sonucuna varılmıştır.
Köprü ayaklarının her birinde 34 adet dört köşe ahşap kazık bulunmaktadır. Kare şeklinde olan kazıkların kenar boyutları 0.3-0.4 metre arasinda değişmektedir. Kazıklara gelen yükü mümkün olduğunca azaltmak için ayaklar içi boş olarak yapılmıştır. Üst yapı yükleri direkt olarak 90x90 cm boyutunda beton kolonlar ve döşeme sistemi ile kazıklara aktarılmaktadır. Toprak itkisini karşılamak üzere doğrudan doğruya zemine oturan ve kazıklardan bağımsız bir betonarme sandık oluşturulmuştur. Ayakta mesnetler çelikten yapılmıştır. Aşağıda Şekil 2'de orijinal çizimler üzerinde köprünün ayak detayları ve kazık bağlantıları görülmektedir (URL-1, 2016).

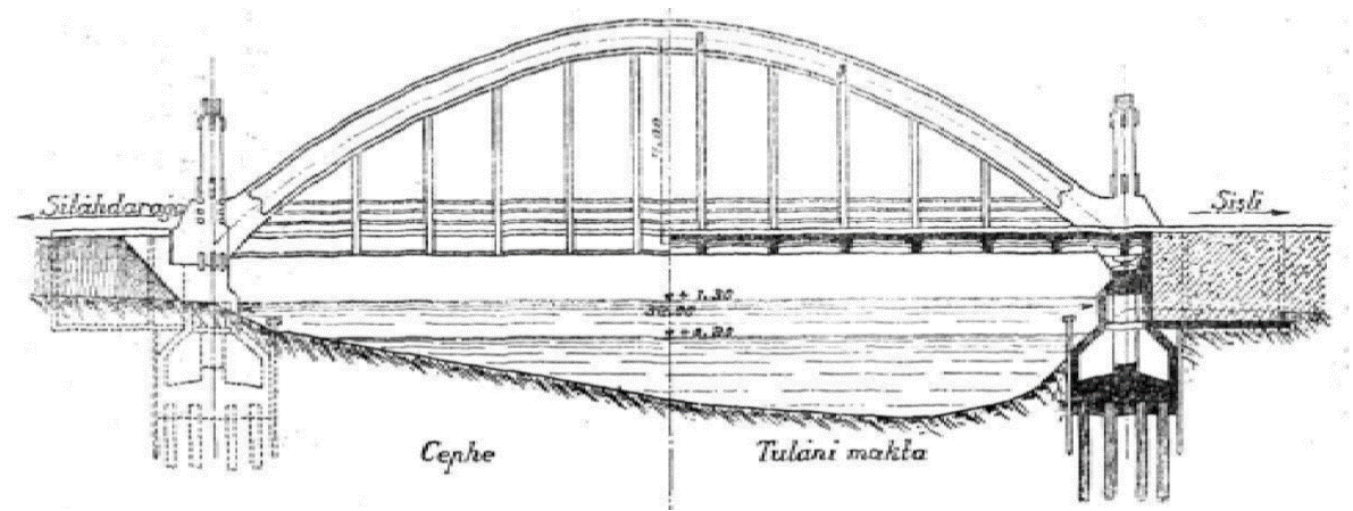

Şekil 2. Köprü ayak detayları ve kazık bağlantıları (URL-1, 2016).

Köprüde kemer açıklığı 38 metre, döșeme genişliği ise 7 metredir. Kemer yüksekliği, üst başlığın tepe noktasından, alt başlık tabanına kadar dıştan dışa $8 \mathrm{~m}$, içten içe ise net 6 metredir (Sert vd., 2015). Üst başlık ve alt başlık birbirlerine, açıklık ortasına göre simetrik yerleştirilmiş, değişken yüksekliklerde ve 50x20 boyutlarında 12 adet kemer askı çubuğuyla bağlanmıştır. Döşeme en dışta iki gergi dışında, boyuna yönde 4 adet kiriş üzerine oturur. Yükleri gergilere aktarmak amacıyla ek olarak 14 adet enine kiriş de bulunmaktadır.

Betonarme kemer taşıyıcı sistem, ülkemizde sıklıkla uygulanmış bir köprü tasarım metodudur. Türkiye'nin farklı bölgelerinde inşa edilmiş değişen açıklık sayısı ve uzunluklarında çeşitli kemer köprü örnekleri bulunmaktadır. 1956 y1lında Fırat Nehri üzerinde inşa edildiğinde 720 metre uzunluğuyla Türkiye'nin en uzun karayolu köprüsü olan Birecik Köprüsü'nün bir kısm1, her biri 55 metre açıklığa sahip olan 5 adet kemerden oluşmaktadır (Bayraktar, 2014).

$\mathrm{Bu}$ tür köprülerin günümüz şartlarında yetersiz kalmalarına yol açan en önemli etkenler, yapıldıkları dönemde kullanılan malzeme kalitesinin günümüz beton ve çelik sınıflarına kıyasla daha düşük olması ve yapısal elemanlarda olumsuz çevresel şartlar sebebiyle zaman içinde oluşan aşınma ve korozyondur. Öte yanda bu köprülerin tasarımlarında esas alınan yük değerleri, taşıt sayı ve profilleri de zaman içinde önemli ölçüde değișmiștir. Yapıldığı dönemlerde yaya ve atlıların geçişini sağlamak için planlanmış köprüler günümüz modern motorlu taşıtların geçişi için elverişli olmayabilir. Özellikle üstlerinden geçen ağır kamyonların zarar vermesi ve çarpması sonucu hasar görmüş ve hatta yıkılmış köprü örnekleri mevcuttur (Akbaş, 2012).

\section{Hasarsiz malzeme testleri ve donatı belirleme çalışmaları}

Köprüdeki yapısal elemanların beton dayanımlarını bulmak için Schmidt çekici yardımıyla tüm askı çubukları (24 adet) üzerinde onar adet ölçüm alınmıştır. Bu ölçümlerin yarısı çubukların ön yüzlerinden, diğer yarısı da yan yüzlerinden alınarak testin uygulandığı yüzeyin alınan ölçümlere etkisi anlaşılmaya çalışılmıştır. Aşağıda Tablo 1'de ölçülen sertlik değerleri (R) özetlenmiştir. Çubuklar, bulundukları aksa göre A ve B olmak üzere gruplandırılmış ve numaralandırılmıştır.

Betonarme elemanların basınç dayanımlarının düşük olması durumunda, sertlik değerlerinden 
basınç dayanımına geçmek için Schmidt çekici üzerinde verilen standart dönüşüm eğrilerinin kullanılmasının \% 60'lara varabilecek hatalara yol açabileceği belirtilmiştir (İlhan, 2000). Bu sebeple dönüşüm eğrilerinin, Schmidt çekici okumalarıyla, aynı yapıdan alınmış karot örneklerinden bulunan değerlerin korrelasyonu yöntemiyle elde edilmesi tavsiye edilmektedir. Bu sebeple bu çalışmada Schmidt çekici üzerinde yer alan dönüşüm eğrileri doğrudan kullanılmamıştır. Köprü üzerinde alınan
Schmidt çekici okumaları, referans çalışmada (İlhan, 2000), benzer güçte bir beton sinıfi için önerilen korrelasyon fonksiyonlariyla analiz edilmiş ve Tablo 1'de gösterilen basinç dayanımları elde edilmiştir. Tabloda da gösterildiği şekilde beton dayanımları $6 \mathrm{MPa}$ ve $15 \mathrm{MPa}$ arasında değişmektedir, 24 askı çubuğu için ortalama dayanım $10.75 \mathrm{MPa}$ olarak hesaplanmıştır.

Tablo 1. Schmidt çekici ölçümleri ve hesaplanan basınç dayanımları

\begin{tabular}{ccccc}
\hline \multicolumn{5}{c}{ Beton Sertlik Değerleri (R) } \\
\hline Askı Çubukları & Ön Yüz & Yan Yüz & Ortalama & Basıç Dayanımı (MPa) \\
\hline A1 & 24 & 26 & 25 & 7 \\
A2 & 30 & 42 & 36 & 14 \\
A3 & 35 & 40 & 38 & 15 \\
A4 & 38 & 35 & 37 & 14 \\
A5 & 28 & 34 & 31 & 11 \\
A6 & 30 & 28 & 29 & 9 \\
A7 & 30 & 35 & 33 & 12 \\
A8 & 34 & 32 & 33 & 12 \\
A9 & 16 & 32 & 24 & 6 \\
A10 & 28 & 30 & 29 & 9 \\
A11 & 29 & 29 & 29 & 9 \\
A12 & 34 & 24 & 29 & 6 \\
B1 & 23 & 25 & 24 & 12 \\
B2 & 25 & 40 & 33 & 7 \\
B3 & 21 & 30 & 26 & 12 \\
B4 & 33 & 33 & 33 & 15 \\
B5 & 41 & 35 & 38 & 11 \\
B6 & 32 & 32 & 32 & 11 \\
B7 & 32 & 32 & 32 & 11 \\
B8 & 24 & 38 & 31 & 14 \\
B9 & 32 & 40 & 36 & \\
B10 & 30 & 40 & 35 & 32 \\
B11 & 32 & 32 & 27 & \\
B12 & 28 & 25 & & \\
\hline
\end{tabular}

Schmidt çekici testlerine ek olarak, Hilti PS 35 donatı tespit ve tarama aygıtı ile askı çubukları taranmıştır. Yapılan incelemelerde çubuklarda, köşelerde birer adet donatı ve uzun kenar boyunca iki sıra gövde donatısı olmak üzere toplam 8 adet $18 \mathrm{~mm}$ çapında betonarme donatısı bulunmuştur. Donatı çapı, beton kaplamanın aşınıp döküldüğü bölgelerde, açığa çıkan çubuklar üzerinde dijital kumpas kullanılarak yapılan ölçümlerle belirlenmiştir. Kullanılan donatılar düz (S220a) çubuklardır, etriye olarak $\phi 6 / 200$ kullanılmıştır. Donatı aralıklarının doğru bir şekilde belirlenebilmiş olmasına karşın, aderans sebebiyle betonun çubuğa yapışması, paslanma ve pullanma sebebiyle donatı çaplarının tespitinde az da olsa bir belirsizlik söz konusu olabilir.

Benzer şekilde kemer üzerinde de donatı sayımları yapılmış, basınç kemerinin alt ve üst yüzeylerinde 10 'ar adet ve gövdede her iki kenarda 5'er adet olmak üzere toplamda 30 adet $\phi 18$ donatı tespit edilmiştir. Basınç kemeri, askı çubukları ve döşeme donatıları ile ilgili yapılan tespitler aşağıda Şekil 3'de gösterilmiştir. 

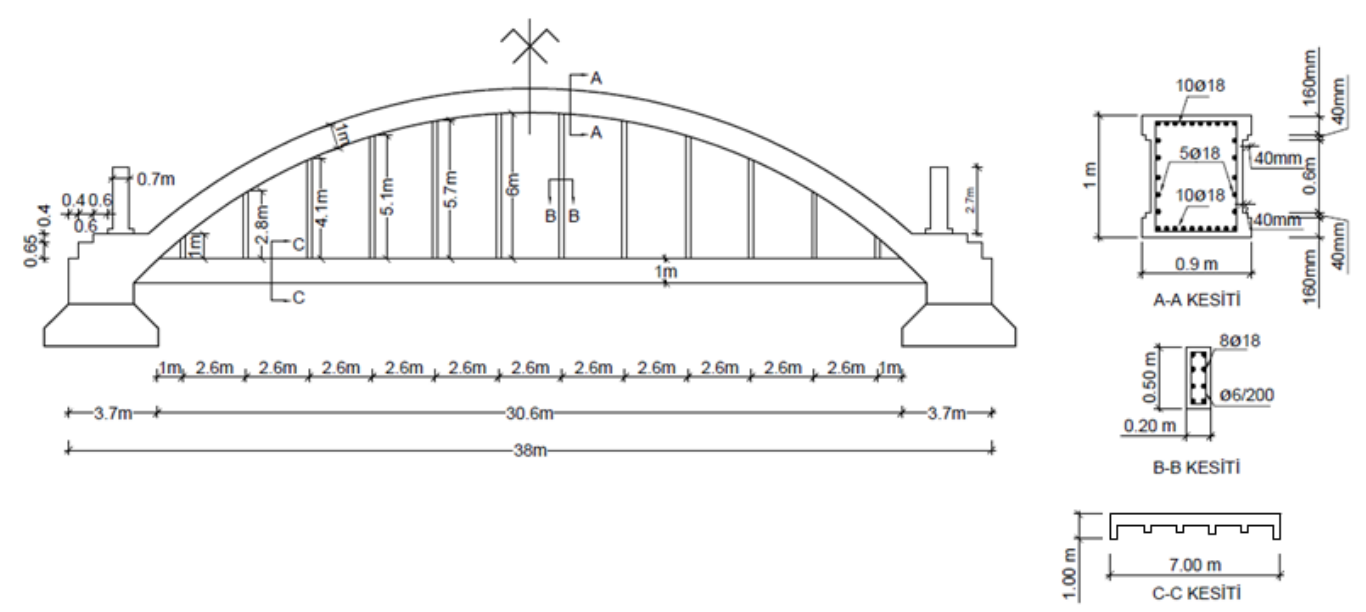

Şekil 3. Köprü eleman kesit boyutları ve donatıları

\section{Basınç eğrisi kontrolü ve yük kapasitesinin hesaplanması}

Kemer türü köprülerin yapısal performanslarının incelenmesinde ve yük taşıma kapasitelerinin hesaplanmasında iki nokta belirleyici olmaktadır. Tasarım prensibi olarak bu sistem, döşemeye etkiyen yüklerin çekme kuvvetleri olarak ask1 çubuklarına, sonra da salt basınç kuvvetleri oluşturacak şekilde üst başlığa aktarılmasına dayanmaktadır. $\mathrm{Bu}$ sebeple öncelikli olarak, döşemeye (alt başlığa) etki eden yüklerin, askı çubukları üzerinde oluşturacağı kuvvetlerin, çubukların çekme kapasitelerini aşıp aşmayacağı kontrol edilmelidir.

Ask1 çubuklarının çekme kapasiteleri hesaplanırken betonun çekme dayanımı ihmal edilmiştir. Donatı olarak kullanılan $8 \phi 18$ S220 donatısının taşıyabileceği yük aşağıdaki şekilde hesaplanabilir. Aşağıda denklem 1'de D donat1 çapını, $\sigma_{y}$ ise akma gerilmesini temsil etmektedir.

$$
\mathrm{F}=\left(8 \pi \frac{D^{2}}{4} \sigma_{y}\right) / 1.15=8\left(254 \mathrm{~mm}^{2}\right)(220 \mathrm{MPa}) / 1.15=390 \mathrm{kN}
$$

Askı çubuklarına etkiyen yüklerin hesaplanmasında her bir çubuk tarafindan taşınan döşeme alanının bulunması önemlidir. Fil Köprüsü'nün boyutları Şekil 3'de gösterilmiştir. Şekilde de görülebileceği üzere askı çubukları arasındaki mesafe 2.6 metredir. Hesaplarda döşeme kalınlığ 0.5 metre ve yol genişliği 7 metre alınmıştır. Betonarme malzemenin özağırlığ 24 $\mathrm{kN} / \mathrm{m}^{3}$ ve ölü yükler $(\mathrm{G})$ için yük katsayısı 1.4 kabul edilerek her bir askı çubuğuna etki eden toplam ölü yük aşağıdaki gibi hesaplanabilir.

$$
1.4 G=(1.4)(0.5 m)(2.6 m)(3.5 m)\left(24 k N / m^{3}\right)=153 k N
$$

Köprü askı çubukları tarafindan güvenle taşınabilecek hareketli yük denklem 1 ve 2 'den bulunan değerlerin farkı alınarak hesaplanabilir.
$\mathrm{Bu}$ yük daha sonra aşağıda gösterildiği şekilde döşeme yüzey alanına bölünerek yayılı yüke çevrilebilir.

$$
1.6 L=390-153=237 k N=(1.6)(2.6 m)(3.5 m) q \Rightarrow q=16.3 k N / m^{2}
$$

Ask1 çubukları tarafından üst başlığa aktarılan yükler, başlığın özel kemer şekli sebebiyle kesitte moment ve çekme gerilmeleri oluşturmamaktadır (Forsyth, 2007). Ancak kesitte oluşan gerilmelerin salt basınç olacağının kabul edilebilmesi için üst başlıkta eksen eğrisinin finüküler biçimde tasarlanıp tasarlanmadığ kontrol edilmeli ve basınç eğrisinin her zaman kesit içinde kalacağından emin olunmalıdır (Şener ve Şener, 2015). Aşağıda Tablo 2'de Fil Köprüsü'nün üst başlığını oluşturan kemerin geometrik özellikleri verilmiştir. Tabloda özetlenen boyutlar ayrıca Şekil 4'de de gösterilmiştir. 
Tablo 2. Kemer Geometrisi ve uzunluklar

\begin{tabular}{lc}
\hline Boyut & Uzunluk - oran \\
\hline b (kemer kesit genişliği) & $0.74 \mathrm{~m}$ \\
h (kesit yüksekliği) & $1.0 \mathrm{~m}$ \\
L (köprü açıklığı) & $34.6 \mathrm{~m}$ \\
$\mathrm{f}$ (kemer oku) & $7.0 \mathrm{~m}$ \\
f/L (basıklık) & 0.20 (oran) \\
\hline
\end{tabular}

Tablo 2'de “ $L$ ” ile gösterilen köprü açıklığı, mesnet (üzengi) noktaları arasındaki mesafedir. Benzer şekilde, kemer oku, "f", kemerin üst noktasının (anahtar), mesnet seviyesinden ölçülen yüksekliği olarak tanımlanabilir. Kemer okunun açıklığa oranı $(f / L)$ kemer basıklığı olarak gösterilmektedir. Genel bir tasarım kuralı olarak bu değerin 0.15 'den büyük seçilmesi gerekmektedir. Fil Köprüsü üzerinde 0.20 olarak hesaplanan basıklık değerinin bu sınırdan yüksek olmasının, yapının yük taşıma kapasitesi üzerine olumlu etkisi olacaktır.

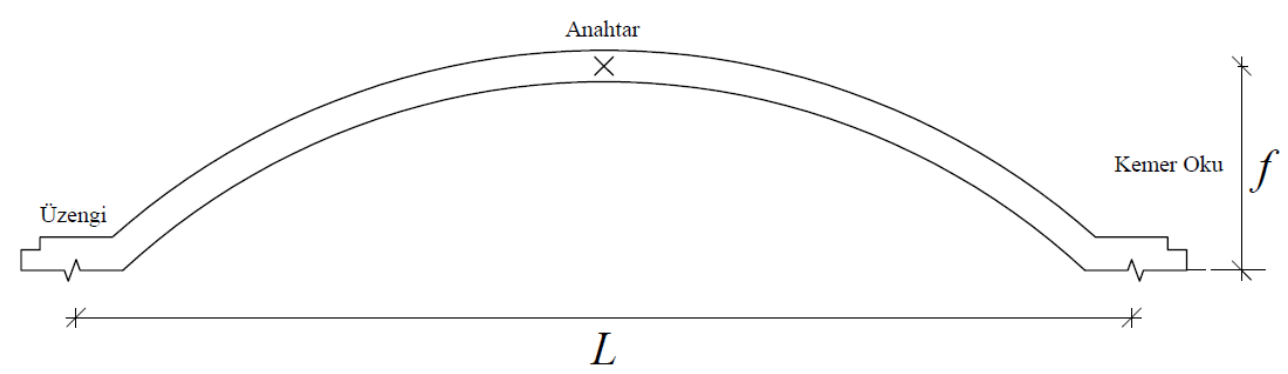

Şekil 4. Kemer özellikleri

Aşağıda Şekil 5 üzerinde yapıya etki eden kuvvetler gösterilmektedir. Yatay eksende köprünün orta noktası merkez kabul edilerek, köprü üzerinde merkezden $x$ birim uzaklıkta bulunan bir nokta için oluşacak moment $M(x)$ denklem 4'te gösterildiği şekilde hesaplanabilir.

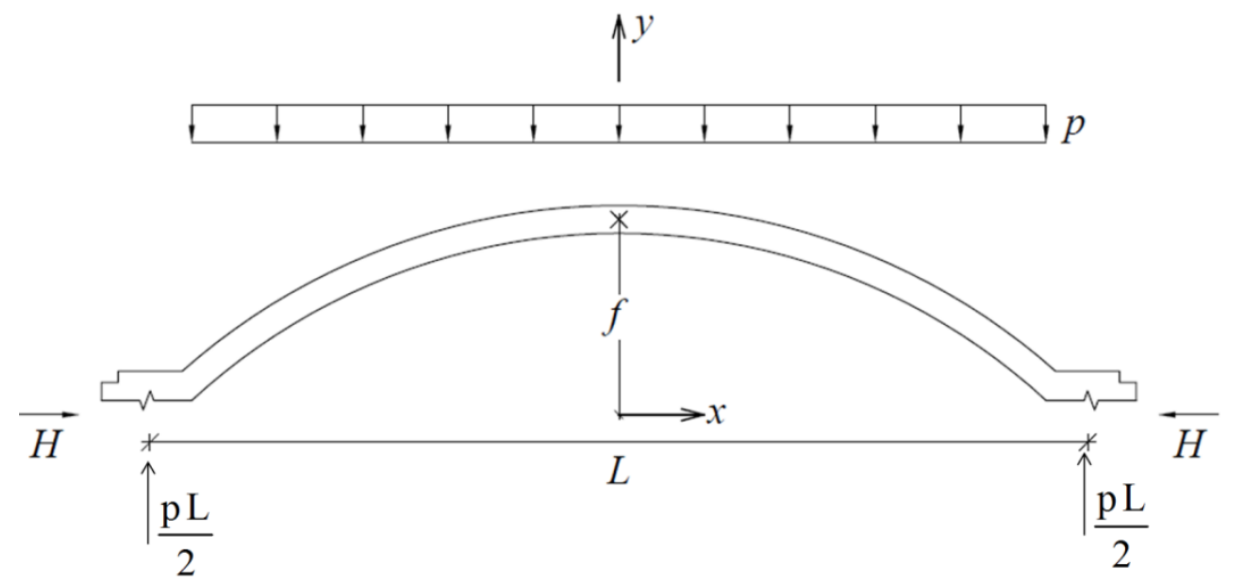

Şekil 5. Köprüye etkiyen yayılı yükler ve mesnet tepkileri

$\sum M=0 \Rightarrow-M(x)-(H)(y)+\left(\frac{p L}{2}\right)\left(\frac{L}{2}-x\right)-\frac{p}{2}\left(\frac{L}{2}-x\right)^{2}=0$

Denklem 4'de kemerin kendi ağrlı̆̆ ihmal edilmiştir, denklem kemer üzerinde alınan tüm noktalarda moment değeri sıfır çıkacak şekilde $M(x)=0$ kabulü yapılarak ve $\xi=\frac{2 x}{L}$ şeklinde boyutsuz bir değişken kullanılarak tekrar yazılırsa denklem 5 elde edilir.

$$
y=\frac{p L^{2}}{4 H}\left[(1-\xi)-\frac{(1-\xi)^{2}}{2}\right]
$$

Denklem 5, $x=0$ için $y=f$ sınır şartları kullanılarak çözüldügünde aşağıda verilen denklem 6 elde edilir. 


$$
f=\frac{p L^{2}}{8 H}
$$

Denklem 6, denklem 5'te yerine yazılınca, köprü kemerinin sahip olması gereken şekli ortaya çıkaran ikinci derece bir eğri fonksiyonu bulunmuş olur.

$$
y=f\left[2(1-\xi)-(1-\xi)^{2}\right]
$$

Denklem 7'den de anlaşılacağı üzere çıkarılan bağıntı sadece kemerin şekli ve boyutlarıyla ilgili olup uygulanan yüklerden bağımsızdır. Köprü uzunluklarına bağlı olarak basınç eğrisinin koordinatlarının nasıl değiştiği, aşağıda Şekil 6'da kesikli çizgilerle gösterilmiştir. Şekilde de görüldüğü gibi basınç eğrisi, köprü üzerindeki tüm noktalarda her zaman kesit içinde kalmaktadır. Elde edilen bu sonuç, köprü kemeri üzerindeki tüm noktalarda her zaman basınç gerilmelerinin etkili olacağını, çekme gerilmesi oluşmayacağını ve dolayısıyla da tasarımın güvenli olduğunu göstermektedir.

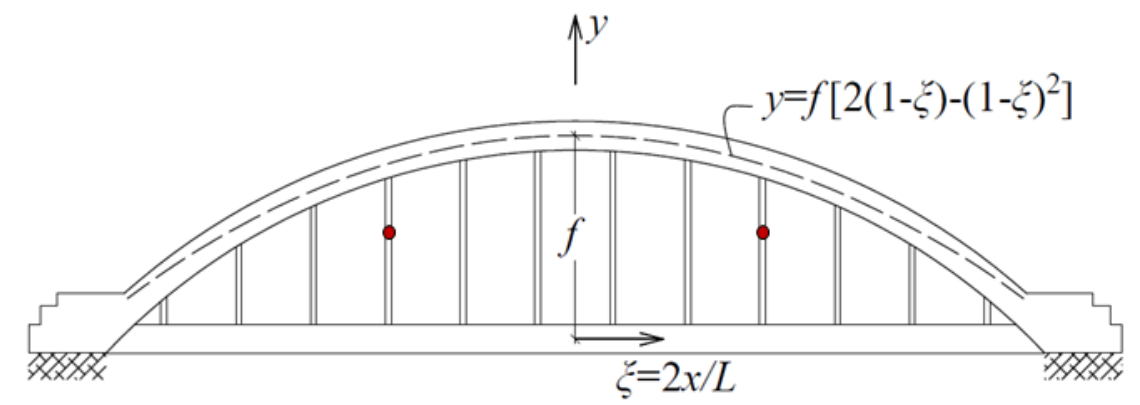

Şekil 6. Üst başlıkta basınç ekseninin değişimi

\section{Köprü üzerinde alınan serbest titreşim ölçümleri}

Yapının dinamik özelliklerinin hesaplanmasında kullanılacak olan bilgisayar modelinin doğrulanabilmesi amaciyla köprü üzerinde ask1 çubuklarına Şekil 7'de gösterildiği gibi 4 adet tek eksenli ivme ölçer yerleştirilmiş ve yapı üzerinde serbest titreşim ölçümleri alınmıştır. Özellikle köprünün hemen yanında bulunan yol üzerinden sıklıkla geçen kamyon ve otobüs türü ağır taşıtların oluşturduğu güçlü titreşim yardımıyla yapı yeterli enerji seviyelerinde uyarılabilmiştir. İvme ölçerler, kayıt alma işlemini kolaylaştırmak adına titreşim genliklerinin daha yüksek olacağının düşünüldüğü ask1 çubukları üzerine düzlem dışı yönde, Şekil 6'da kırmızı renkle gösterilen noktalara her iki aksta ikişer tane olacak şekilde yerleştirilmiştir.
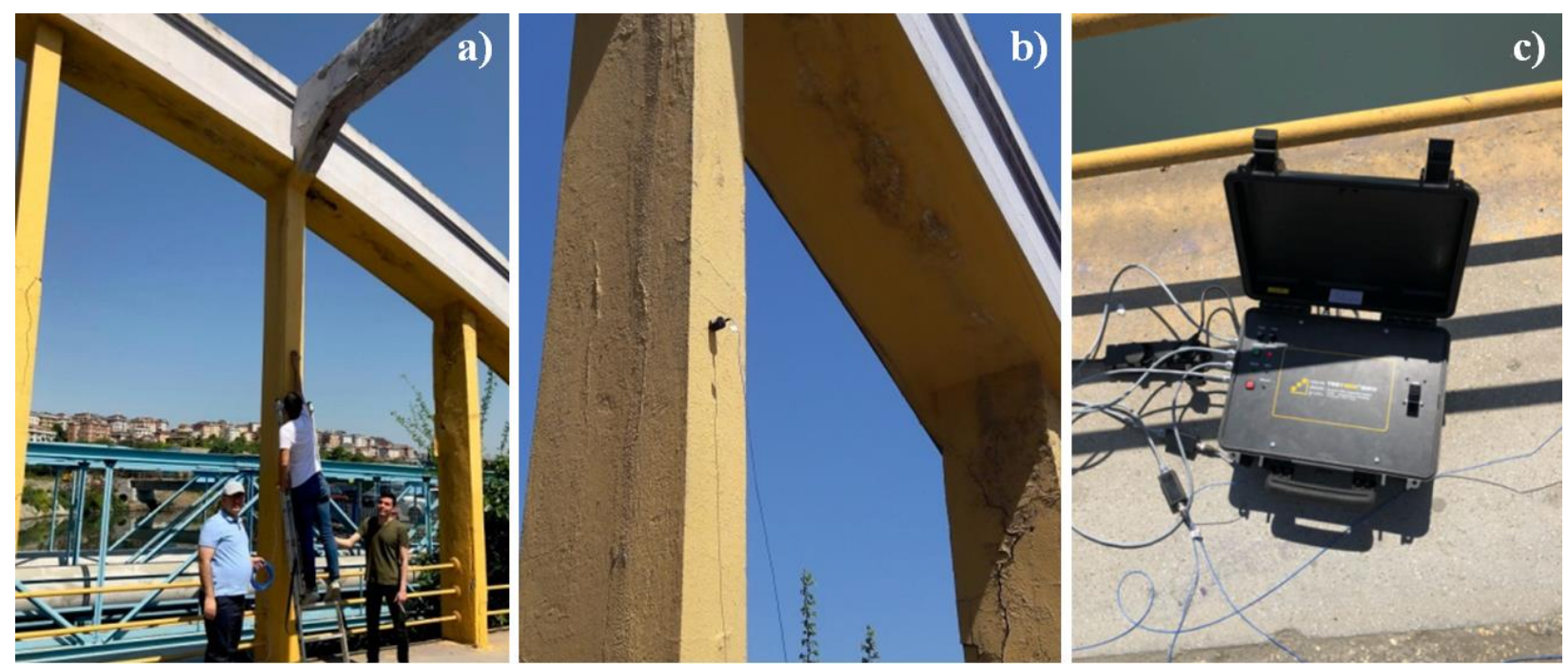

Şekil 7. (a) İvme ölçerlerin yerleştirilmesi (b) İvme ölçer konumu (c) Veri toplama sistemi

Ölçümlerde kullanılan PCB 393B04 marka tek eksenli ivme ölçer, yapısal sağlik kontrolü uygulamalarında siklıkla tercih edilen ve $0.06-450$
$\mathrm{Hz}$ frekans aralı̆̆ında çok yüksek hassasiyette ölçüm alabilen bir sensördür (URL-2, 2020). Veri toplama sistemi olarak $200 \mathrm{~Hz}$ ölçüm frekansında 
okuma alabilen TestBox 2010 model dinamik veri toplama sistemi kullanılmıştır (URL-3, 2020). Testler sirasinda $200 \mathrm{~Hz}$ örnekleme frekansinda 15-20 dakika arasında değişen sürelerde ölçümler alınmıştır. Aşağıda Şekil 8'de alınan ivme kayıtlarından bir örnek sunulmuştur. Şekilde de görüleceği üzere köprünün hemen yanında bulunan yol üzerinden sıklıkla geçen ağır taşıtlar, 64 saniye gibi kısa bir süre içinde dahi yapıyı birkaç kez yüksek enerji seviyelerinde titreştirebilmiştir.

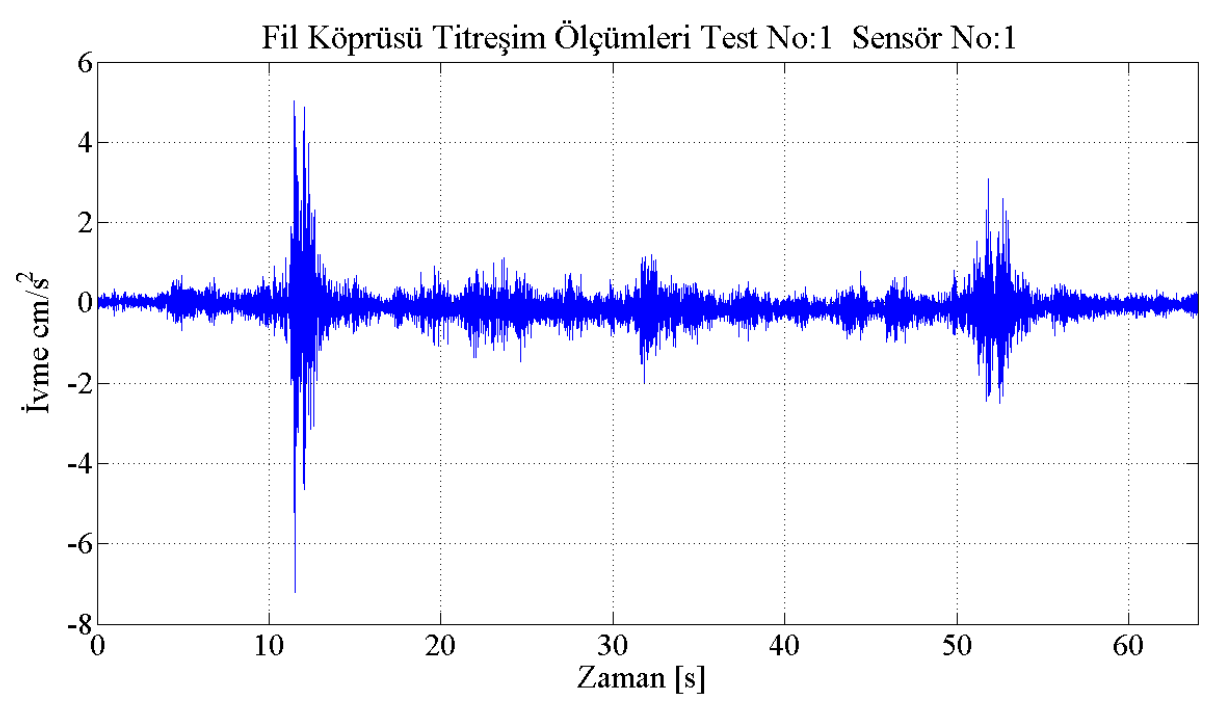

Şekil 8. Köprü üzerinde alınan titreşim ölçümlerine bir örnek

Yap1 üzerinde alınan ölçümlerin frekans tanım aralığında analizi sonucu elde edilen Güç Spektral Yoğunluk (Power Spectral Density) grafiği aşağıda Şekil 9'da sunulmuştur. Şekilde gösterilen grafik $200 \mathrm{~Hz}$ ölçüm frekansında kaydedilmiş 64 saniyelik blokların güç yoğunluk değerlerinin ortalamaları alınarak hesaplanmıştır. Bu amaçla 64 saniyelik analiz bloğu her adımda 32 saniye kaydırılarak 1120 saniyelik titreşim ölçüm verisi taranmıştır. Şekil 9'da sunulan grafik tüm ölçümün bu şekilde incelenmesi sonucu bulunan 35 adet farklı Güç Spektal Yoğunluk grafiğinin ortalaması alınarak elde edilmiştir.

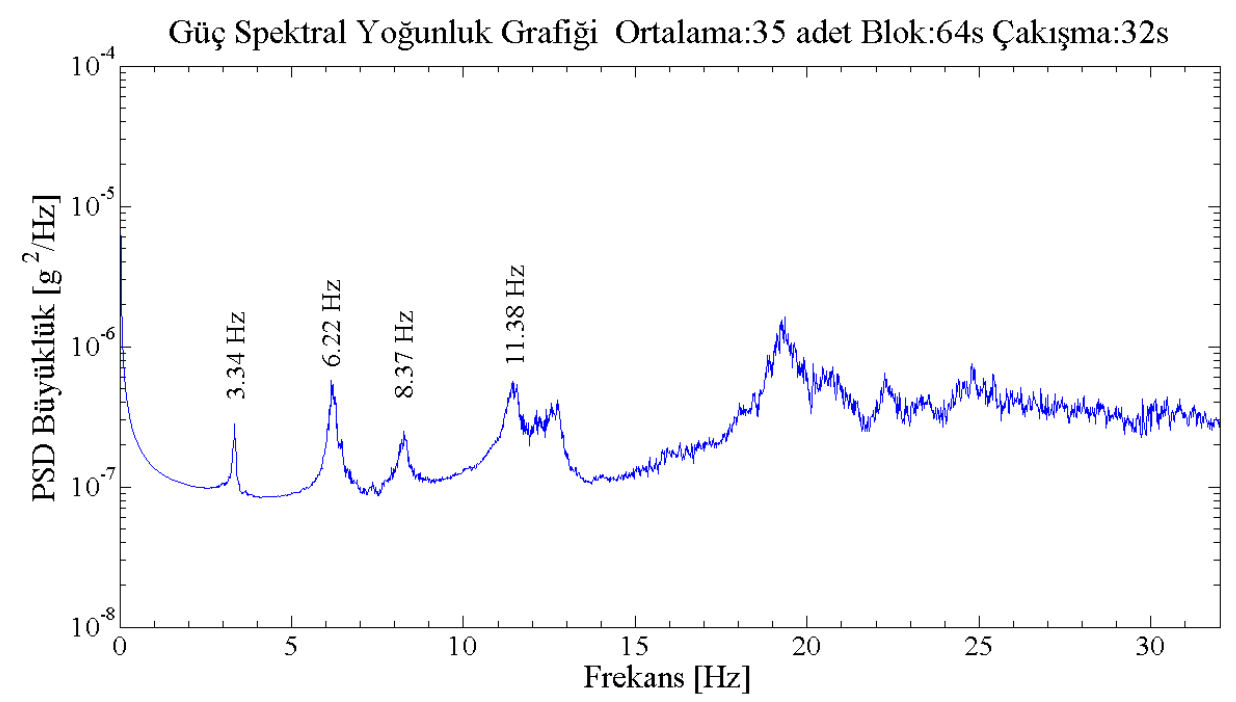

Şekil 9. Köprü üzerinde alınan titreşim ölçümlerinin Güç Spektral Yoğunluk grafiği

Gerçekleştirilen testler sonucu elde edilen titreşim verisi, Artemis Modal programı kullanılarak analiz edilmiştir. Bu yazılımda sistem geometrisi, sensör konumları ve ölçüm yönleri tanımlanarak, test edilen yapının bir modeli oluşturulmaktadır. Modelin kurulmasını takiben, kaydedilen titreşim verisi, çeşitli dinamik analiz yöntemleriyle çözümlenerek frekans, sönümleme oranları ve mod şekilleri gibi modal parametreler hesaplanmakta ve karşılaştırmalı olarak incelenebilmektedir (URL-4, 2020).

Köprü üzerinde alınan ölçümlerin analizi sonucu gözlemlenebilen modlar aşağıda Tablo 3'de 
sunulmuştur. Elde edilen bu değerler, daha sonra oluşturulan SAP2000 (URL-5, 2020) modelinin kalibrasyonunda kullanılmıştır. Model doğrulama olarak bilinen bu uygulamada, model üzerinde özdeğer analizi (Eigenvalue analysis) yapılarak elde edilen doğal titreşim periyotlarının, saha testlerinden elde edilen periyotlarla aynı veya çok yakın değerlerde olması, modelin doğruluğunu ve gerçek sistemi ne ölçüde temsil edebileceğini gösteren önemli bir ölçüttür (Cho vd., 2019).

$\mathrm{Bu}$ amaçla bilgisayar modeli oluşturulurken girilmesi gerekli olan Elastisite Modülü, bağlant1 noktalarının rijitlikleri gibi bazı değerler, hesaplanan ve gözlemlenen periyot değerleri yakın sonuçlar verecek şekilde güncellenmektedir (Hester vd., 2019). Bilgisayar modellerinin daha detaylı analizler için kullanımı ancak saha testleriyle doğrulandıktan sonra mümkün olabilmektedir (Xia vd., 2020).

\section{SAP2000 modelinin kurulumu ve model kalibrasyonu}

Alınan ölçümlerle de doğrulanan köprü planı ve malzeme özellikleri kullanılarak, SAP2000 programı yardımıyla yapının bilgisayar modeli oluşturulmuştur. Ortalama basınç dayanımı 10.75 MPa çıkan beton için Elastise Modülü aşağıda verilen denklem 8 kullanılarak $24656 \mathrm{MPa}$ olarak hesaplanmıştır (TS500). Denklem 8'de $f_{c k}$ betonun karakteristik basınç dayanımını temsil etmektedir.

$$
E=3250 \sqrt{f_{c k}}+14000[M P a]
$$

SAP2000 modeli daha sonra, sahada alınan titreşim ölçümlerinden elde edilen periyotlarla ölçeklendirilmiştir. $\mathrm{Bu}$ amaçla denklem 8 kullanılarak $24656 \mathrm{MPa}$ olarak hesaplanan Elastisite Modülü programa girilirken 24000 olarak alınmıştır. Kalibrasyon sırasında kullanılan periyotlar aşağıda Tablo 3'de görülmektedir. Titreşim verisinin analizinden elde edilen frekansların SAP2000 modelinden bulunan modlarla eşleştirilemesi amacıyla SAP2000 programından elde edilen teorik mod şekilleri ve Artemis Modal programiyla hesaplanan deneysel mod şekilleri karşılaştırılmıştır. Ancak Artemis programında görülebilecek mod şekillerindeki düğüm sayıs1, sadece sensör yerleştirilen ve ölçüm alınan 4 nokta ile sınırlı olduğu için çözünürlüğü yüksek değildir. Bu sebeple gözlemlenen deneysel modların teorik modlarla eşleştirilmesi sırasında frekans değerlerinin yakınlığına, ölçüm noktalarının titreşim yönlerinin ve birbirlerine göre titreşim fazlarının teorik ve deneysel mod şekillerinde aynı olmasına olmasına dikkat edimiş̧ir.

Tablo 3. SAP2000 modelinden ve titreşim ölçümlerinden elde edilen periyotlar

\begin{tabular}{cccccc}
\hline \multicolumn{2}{c}{ SAP2000 Modeli } & \multicolumn{2}{c}{ Titreşim Ölçümü } & & \\
\hline Frekans [Hz] & Periyot [san] & Frekans [Hz] & Periyot [san] & \% Fark & Modal Sönümleme \\
\hline 3.33 & 0.300 & 3.34 & 0.299 & $\% 0.30$ & $\% 1.38$ \\
6.07 & 0.165 & 6.22 & 0.161 & $\% 2.41$ & $\% 1.72$ \\
8.73 & 0.115 & 8.37 & 0.119 & $\% 4.30$ & $\% 1.65$ \\
10.76 & 0.093 & 11.38 & 0.088 & $\% 5.45$ & $\% 1.94$ \\
\hline
\end{tabular}

$\mathrm{Bu}$ noktada Elastisite Modülünün, Schmidt çekici gibi basit bir malzeme testiyle ne derece doğru hesaplanabileceği de sorgulanabilir. Malzeme testlerinde kullanılan Schmidt çekici ölçümlerinde, eğer cihazın üzerinde verilen dönüşüm eğrileri doğrudan kullanılırsa hata payının \%60 mertebesinde olabileceği belirtilmiştir (İlhan, 2000).

Ancak bu çalışmada Schmidt çekicinin üzerinde verilen standart dönüşüm eğrileri doğrudan kullanılmamıştır. Referans alınan çalışmada (İlhan, 2000), köprüdeki askı çubuklarıyla benzer güçte bir beton sınıfı için önerilen korrelasyon fonksiyonları kullanılarak hesaplamalar gerçekleştirilmiştir. Referans çalışma ise bu fonksiyonları, Schmidt çekici okumalarıyla, aynı yapıdan alınmış karot örneklerinden bulunan değerlerin korrelasyonunu hesaplayarak çıkarmıştır. Yukarıda Tablo 1'de sunulan değerler de bu fonksiyonlar kullanılarak hesaplandığı için doğruluklarının yüksek olması beklenmektedir.

Buna ek olarak yapının hesaplanan periyotlarının Elastisite Modülüne bağlı olarak nasıl değişeceği konusunda tek serbestlik dereceli örnek bir sistem üzerinde Duyarlılık Analizi (Sensitivity Analysis) gerçekleştirilmiştir. Aşağıda Şekil 10'da gösterilen tek serbestlik dereceli sistem için titreşim periyodu denklem 9 kullanılarak hesaplanabilir. Denklem 9 da $m$ yapının kütlesini, $k$ elemanın rijitlik değerini temsil etmektedir. 


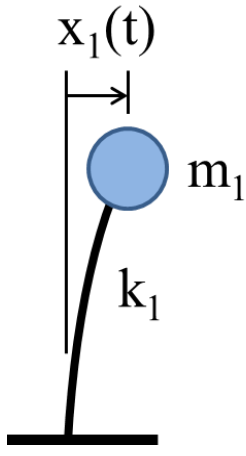

Şekil 10. Duyarlılık analizinde kullanılan tek serbestlik dereceli sistem

$T=2 \pi \sqrt{\frac{m}{k}}$

Rijitlik değeri $k$ kolonun uç noktasının dönebildiği varsayılarak denklem 10 yardımıyla hesaplanabilir. Denklem 10 'da $L$ kolon yüksekliği, $I$ ise eylemsizlik momenti olup tamamen elemanın şekline ve boyutlarına bağlıdır. Denklemden de görülebildiği gibi $k$ rijitlik değeri, $E$ Elastisite Modülüyle doğru orantılıdır.

$$
k=3 \frac{E I}{L^{3}}
$$

Denklem 10, denklem 9 içine yazılarak denklem 11 elde edilir. Denklem 11'de görüldügüü üzere $T$ periyot, Elastisite Modülünün karekökü ile ters orantılıdır. Denklem 11 kullanılarak çeşitli beton basınç dayanım değerleri için yapının periyodunun nasıl değiştiği aşağıda Tablo 4'de gösterilmiştir. Tablo 4'de basınç dayanımı ile Elastisite Modülü $E$ arasındaki bağıntı denklem 8 kullanılarak hesaplanmıştır. İşlemlerde kolaylık olması açısından $E$ harici tüm parametreler $(m, L, I)$ bir olarak kabul edilmiştir.

$T=2 \pi \sqrt{\frac{m L^{3}}{3 E I}}=\frac{2 \pi}{3} \sqrt{\frac{m L^{3}}{E I}}$

Tablo 4'de betonun gerçek basınç dayanımı 10.75 MPa olarak varsayılmış ve buna karş1lık gelen Elastisite Modülü ve periyot değerleri doğru olarak kabul edilmiştir. Daha sonra Schmidt Çekici analizinden bulunduğu varsayılan çeşitli tahminler için dayanım hata oranları ve bu hatalı değerler kullanılarak bulunan hatalı periyotların gerçek periyottan sapma oranları hesaplanmıştır. Mesela Schmidt çekici okumasından elde edilecek değerin $15 \mathrm{MPa}$ olması durumunda dayanım tahmininde yapilan hata $\% 40$ mertebesinde iken, $15 \mathrm{MPa}$ dayanıma karş1lık gelen Elastisite Modülü (26587 $\mathrm{MPa})$ kullanilarak hesaplanan periyotta hata pay1 \%3,7 seviyesinde kalmaktadır. Tablodan da anlaşılacağı üzere incelenen dayanım aralığında yapısal periyotlar Schmidt çekici değerlerine karş1 çok yüksek bir duyarlılı̆̆a sahip değildir. Dayanım hata oranının $\% 60$ mertebesinde olduğu tahminler için bile periyot hata payı en fazla $\% 5,1$ mertebesindedir. $\mathrm{Bu}$ açıdan incelendiğinde SAP2000 ve titreşim ölçümlerinin karşılaştırıldığ1 Tablo 3'te yapının davranışında etkili olan düşük frekanslı ilk birkaç mod için belirlenen periyot farklılikları (\%0,3 ve \% 2.4) oranları makul sınırlar içinde kalmakta ve dönüşüm eğrileri yerine korrelasyon fonksiyonlarını kullanarak hesapladığımız basınç dayanımlarında hata payının çok daha düşük olduğunu doğrulamaktadır.

Tablo 4. Yapısal periyotların Elastisite Modülüne bağlı olarak değişimi

\begin{tabular}{ccccc}
\hline $\begin{array}{c}\text { Schmidt Cekici Analizi } \\
{[\mathbf{M P a}]}\end{array}$ & $\begin{array}{c}\text { Dayanım Hata Payı } \\
{[\mathbf{\%}]}\end{array}$ & $\begin{array}{c}\mathbf{E} \\
{[\mathbf{M P a}]}\end{array}$ & $\begin{array}{c}\text { Normalize Periyot } \\
\text { T (sn) }\end{array}$ & $\begin{array}{c}\text { Periyot Hata Payı } \\
{[\%]}\end{array}$ \\
\hline 7 & $\% 35$ & 22599 & 1.045 & $\% 4.5$ \\
8 & $\% 26$ & 23192 & 1.031 & $\% 3.1$ \\
9 & $\% 16$ & 23750 & 1.019 & $\% 1.9$ \\
10 & $\% 7$ & 24277 & 1.008 & $\% 0.8$ \\
$* \mathbf{1 0 . 7 5}$ & $\% \mathbf{0}$ & $\mathbf{2 4 6 5 6}$ & $\mathbf{1 . 0 0 0}$ & $\% \mathbf{0 . 0}$ \\
12 & $\% 12$ & 25258 & 0.988 & $\% 1.2$ \\
13 & $\% 21$ & 25718 & 0.979 & $\% 2.1$ \\
14 & $\% 30$ & 26160 & 0.971 & $\% 2.9$ \\
15 & $\% 40$ & 26587 & 0.963 & $\% 3.7$ \\
16 & $\% 49$ & 27000 & 0.956 & $\% 4.4$ \\
17 & $\% 58$ & 27400 & 0.949 & $\% 5.1$ \\
\hline
\end{tabular}

*sembolü ile gösterilen $10.75 \mathrm{MPa}$ doğru olarak kabul edilmiş ve diğer tahminler için yapılan hataların hesaplanmasında baz olarak kabul edilmiştir 


\section{SAP2000 modeli ve analiz sonuçları}

Geometri ve malzeme özelliklerinin girilmesini takiben yapı üzerinde özdeğer analizi (Eigenvalue analysis) yapılarak köprünün salınım periyotları ve mod şekilleri hesaplanmıştır. Elde edilen titreşim periyotları ve şekillerinden başlıcaları aşağıda Şekil 11 - Şekil 14'de gösterilmektedir. Köprü modellenirken Şekil 11'e göre yapının sol tarafında bulunan mesnetler sabit mesnet, sağ tarafinda kalan mesnetlerse hareketli (kayıc1) mesnet olarak atanmıştır. Askıların kemer ve tabliyelere bağlantıları rijit olarak modellenmiştir. Köprü üzerinde askı çubuklarında gözlemlenen lokal hasarların modele yansıtılabilmesi için ask1 çubuklarının yapıldığı 20x50 dörtgen kesitler için, 2 ve 3 lokal eksenleri etrafindaki eylemsizlik momenti etki katsayıları 0.85 ile çarpılarak kesitlerin rijitlikleri azaltılmıştır. 0.85 katsayısına parametrik bir analiz yapılarak karar verilmiştir. $\mathrm{Bu}$ katsayıların değişimi aynı anda birkaç modal frekans1 etkilediği için optimum bir değer belirlenmeye çalıșılmıştır. Her 2 aksta da kemerler üzerinde önemli bir hasar bulunmadığı için kemerler için herhangi bir hasar durumu modellenmemiştir.

Taşıyıcı elemanlarda mevcut kesit kayıpları ve hasar etkilerini dolaylı olarak yansıtan bir yaklaşım da malzeme özelliği olarak girilen Elastisite modülü değeridir. Bölüm 5'de de gösterildiği üzere modal parametrelerin, elastisite modülüne karşı yüksek bir duyarlılığ yoktur. Elastisite modülü hesaplanırken ortalama $10.75 \mathrm{MPa}$ olarak kullanılan değer, en düşük ölçümlerden birine karşıllık gelen $7 \mathrm{MPa}$ olarak alınmış olsa dahi, dinamik analizlerde bu durumun yapının davranışında belirleyici olan düşük frekanslı ilk birkaç modun titreşim periyoduna etkisi sadece $\% 4.5$ mertebesinde olacaktır.

Titreşim yönlerinin daha iyi gözlemlenebilmesi amaciyla, şekillerde 3 boyutlu çizimlere ek olarak, modal deformasyonların üstten görünümleri de sunulmuştur. Benzer şekilde, SAP2000 programı yardımıyla çeşitli katsayılarla ölçeklendirilerek, modal deformasyonların genlikleri artırılmış ve bu sayede salınım şekilleri daha da belirginleştirilmiştir.
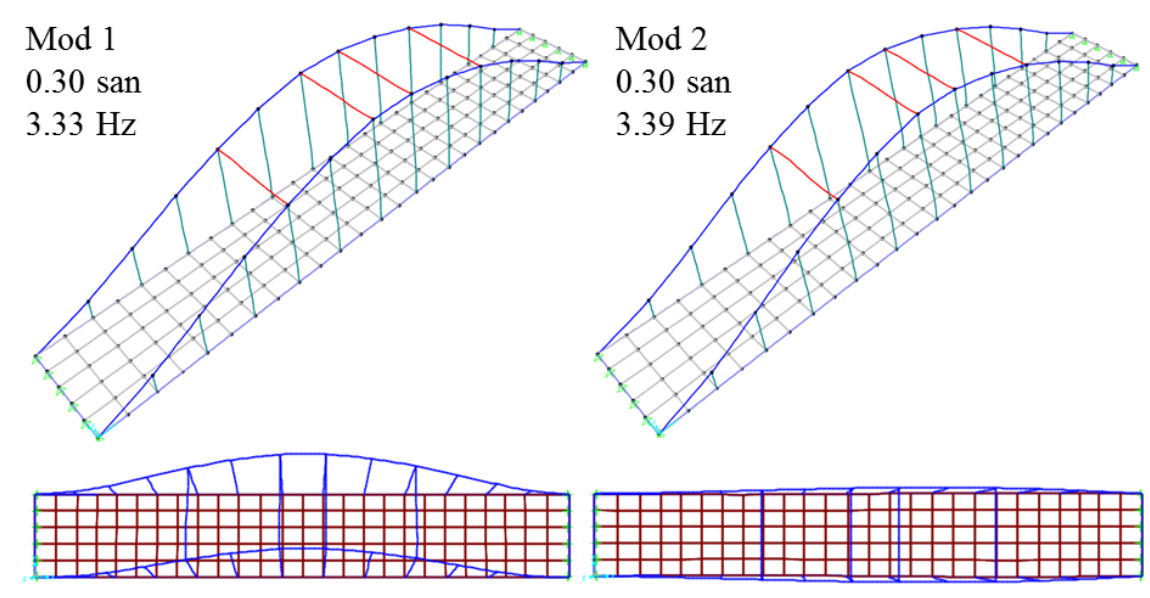

Şekil 11. SAP2000 titreşim modları (a) Mod 1, (b) Mod 2
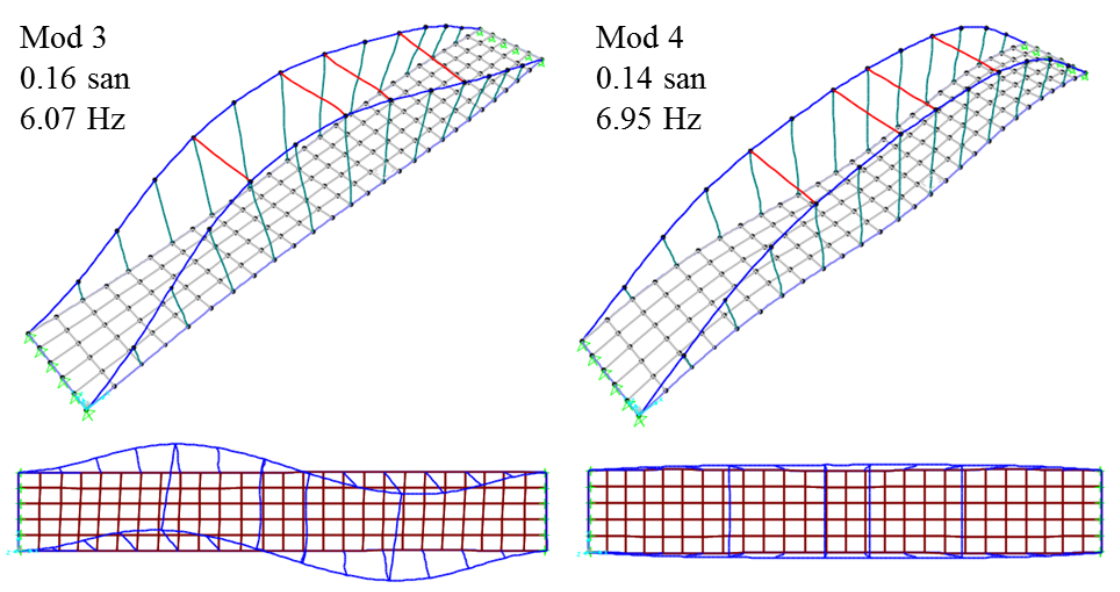

Şekil 12. SAP2000 titreşim modları (a) Mod 3, (b) Mod 4 
Gözlemlenebilen periyotların hangi modlara karşılık geldiği yukarıda verilen şekillerden kontrol edildiğinde, bu modların aslında askı çubuklarının düzlem dışı deformasyonlarının yüksek olduğu salınım modları olduğu görülecektir. Bu gözlem tek eksenli ivme ölçerlerin askı çubukları üzerinde yerleştirilme yönleriyle uyumludur. Tablo 3'te ayrıca köprü üzerinde alınan ölçümlerden hesaplanan modal sönümleme oranları da verilmektedir.

Ölçümler sonucu belirlenen frekansların SAP2000'den elde edilen teorik modlarla eşleştirilmesi sırasında teorik ve deneysel mod şekilleri karşılaştırılmıştır. Deneysel mod şekilleri
Artemis programı yardımıla elde edilmiştir. Ancak bu mod şekillerinde gösterilen düğüm sayısının ölçüm noktası sayısı olan 4 ile sınırlı olması sebebiyle çözünürlük yüksek değildir. Ancak bu durumda bile kısmi bir karşılaştırma yapılması mümkün olmuştur. Teorik ve deneysel mod şekilleri karşılaştırılırken

- Frekans değerlerinin yakınlığına

- Ölçüm noktalarının titreşim yönlerinin teorik ve deneysel mod şekillerinde aynı olmasina

- Ölçüm noktalarının birbirlerine göre titreşim fazlarının teorik ve deneysel mod şekillerinde aynı olmasına dikkat edilmiştir.
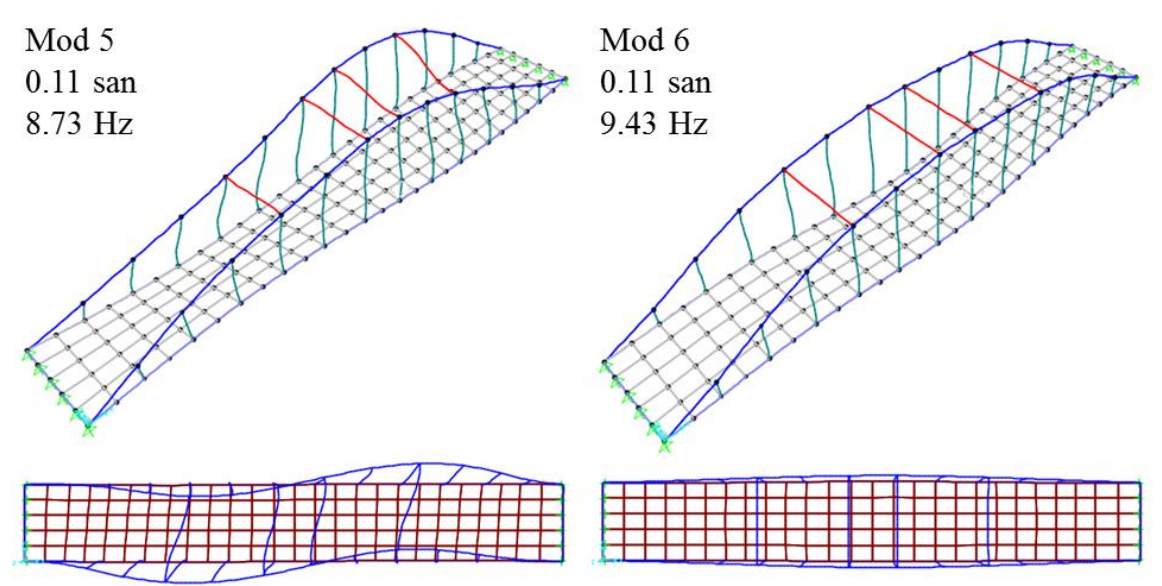

Şekil 13. SAP2000 titreşim modları (a) Mod 5, (b) Mod 6
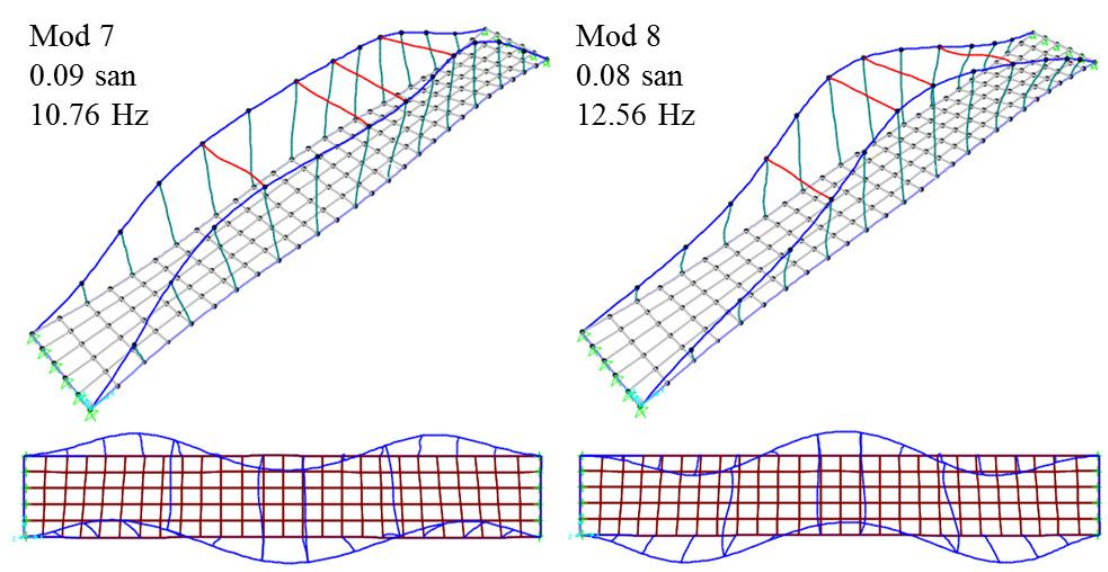

Şekil 14. SAP2000 titreşim modları (a) Mod 7, (b) Mod 8

\section{Köprü üzerindeki yapısal hasar durumu ve köprünün yıkım kararı}

1932 yılında inşa edilen Fil Köprüsü 86 y1llık servis ömrü boyunca sadece 90'lı y1llarda dar kapsamlı bir bakım görmüş (Bakırtaş, 2013), bunun dışında herhangi bir güçlendirme ve onarım yapılmamıştır.
Uzun yıllar boyunca maruz kaldığı yüksek nem ve benzeri zararlı çevresel etkiler sebebiyle donatilarda korozyon, betonarme elemanlar üzerinde ise aşınma ve yer yer dökülmeler meydana gelmiştir. Aşağıda Şekil 15, Şekil 16 ve 17 'de bu hasarın boyutları net bir biçimde görülebilmektedir. Şekil 15-17'de gösterilen fotoğraflar köprü kontrollü bir şekilde y1kılıp kaldırılmadan birkaç ay önce yazarlar tarafindan çekilmiştir. 


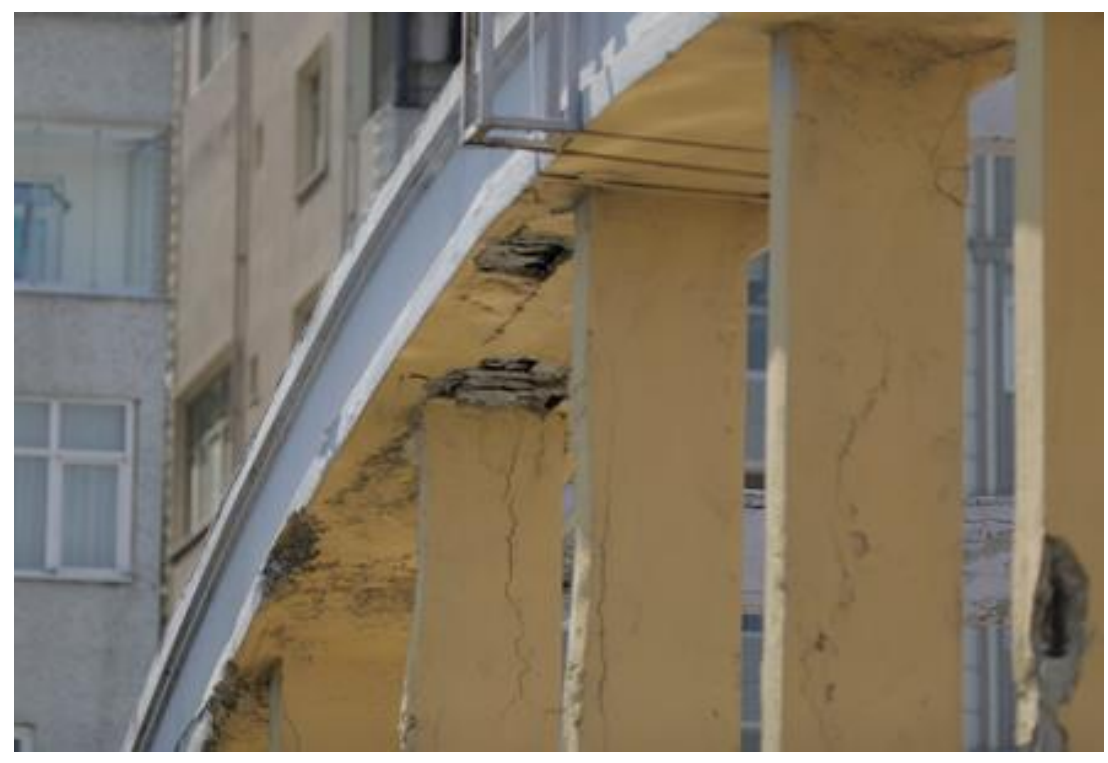

Şekil 15. Basınç kemeri bağlantı noktasındaki hasar, (Fotoğraf yazarlar tarafından çekilmiştir)

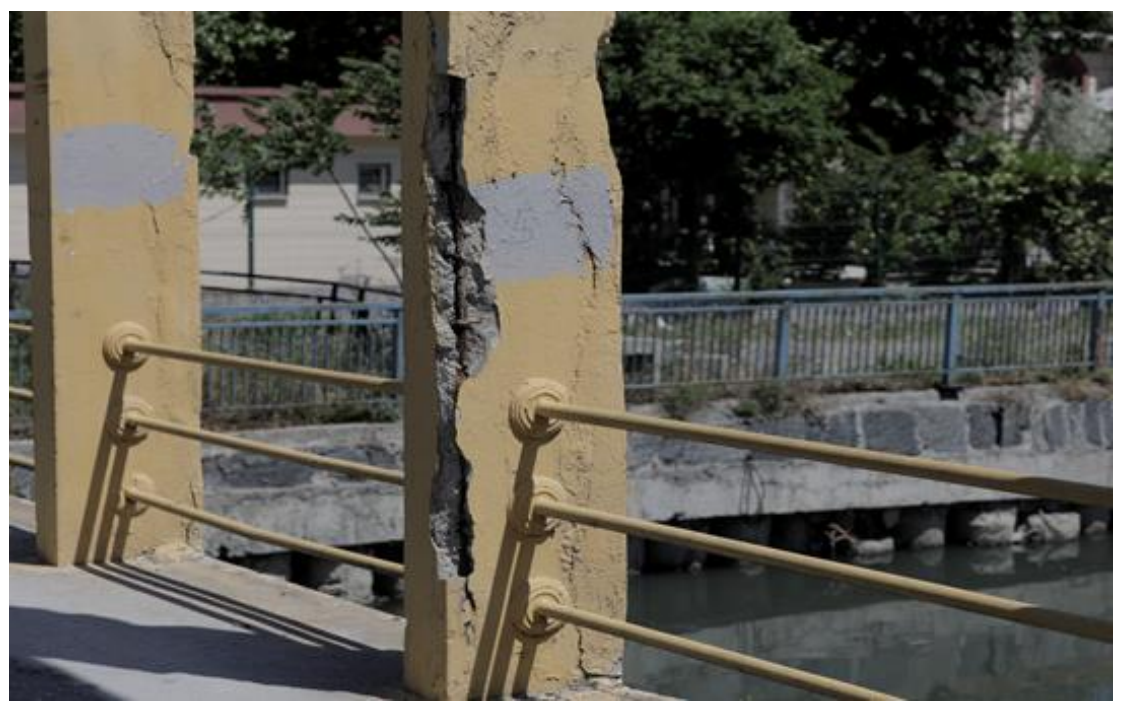

Şekil 16. Askı çubuklarındaki aşınmalar (Fotoğraf yazarlar tarafından çekilmiştir)

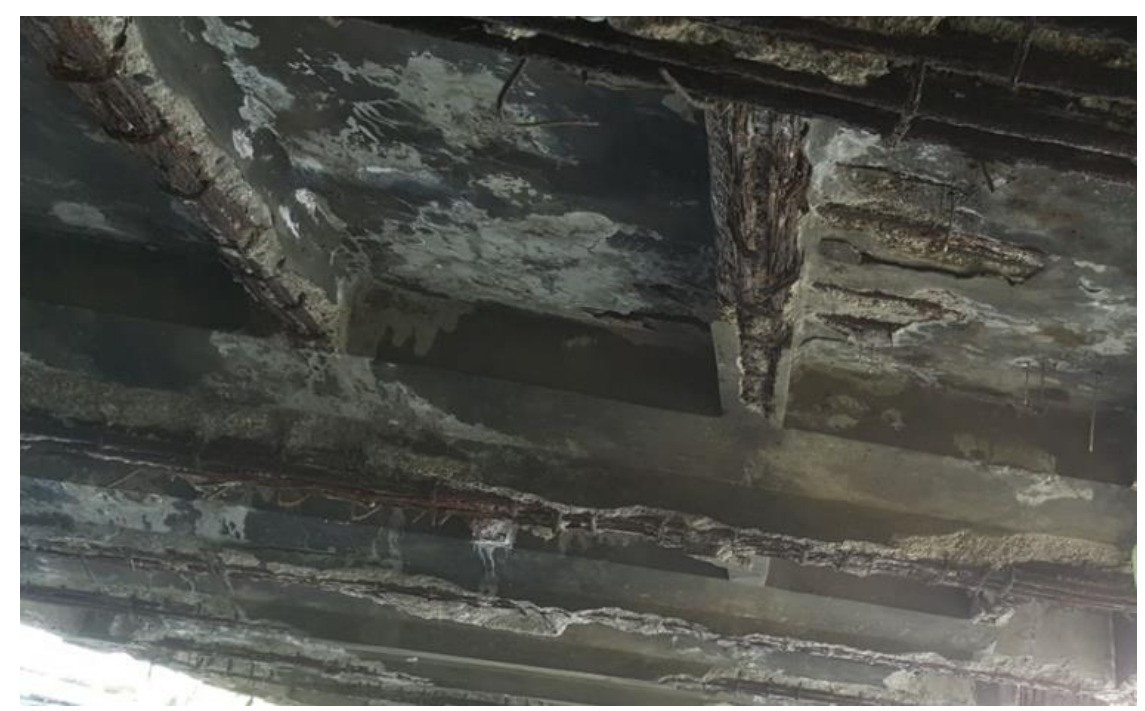

Şekil 17. Köprünün altbaşlığında oluşan aşınmalar ve donatılarda görülen korozyon (Fotoğraf yazarlar tarafindan çekilmiştir) 
Yukarıda verilen şekillerden de anlaşılacağı üzere yap1 tasarım ömrünün sonuna ulaşmış, motorlu taşıt trafiğine kapalı olan köprü, yaya trafiği için bile güvenli hizmet sağlayamaz bir duruma gelmiştir. Kaldı ki yapının mevcut haliyle yakın gelecekte olmas1 muhtemel bir depreme dayanmas1 da mümkün görünmemektedir. Tüm bu şartlara ek olarak, Haliç tramvay hattı inşaası kapsamında yapılması planlanan yol genişletme çalışmaları için mevcut köprününün yıkılıp 50 metre ötede yeni bir köprünün yapılması zorunluluğu da ortaya çıkınca Eylül 2018 tarihinde tarihi Fil Köprüsü çevreye zarar vermeden kontrollü bir şekilde yıkılıp kaldırılmıştır (Şekil 18).
2020 y1lında tamamlanan Kars Barajının suları altında kalacak olması sebebiyle, 2014 yılında bulunduğu yerden kaldırılarak yaklaşık $25 \mathrm{~km}$ uzaklıkta bulunan Kars Üniversitesi yerleşkesi içine taşınan 100 tonluk Tarihi Çamçavuş (Demir) Köprüsü örnek alınarak (Öngören, 2014; Sert vd., 2015), Fil Köprüsü’nün Bilgi Üniversitesi yerleşkesi içine taşınması gündeme gelmiştir. Ancak çelik konstrüksiyona sahip Çamçavuş köprüsünden farklı olarak betonarme tarzda inşa edilmiş ve çeşitli yapısal elemanlarında kısmi hasarlar bulunan Fil Köprüsü'nün vinçler yardımıyla hasar görmeden kaldırılmasının mümkün olmadığı sonucuna varılmıştır.

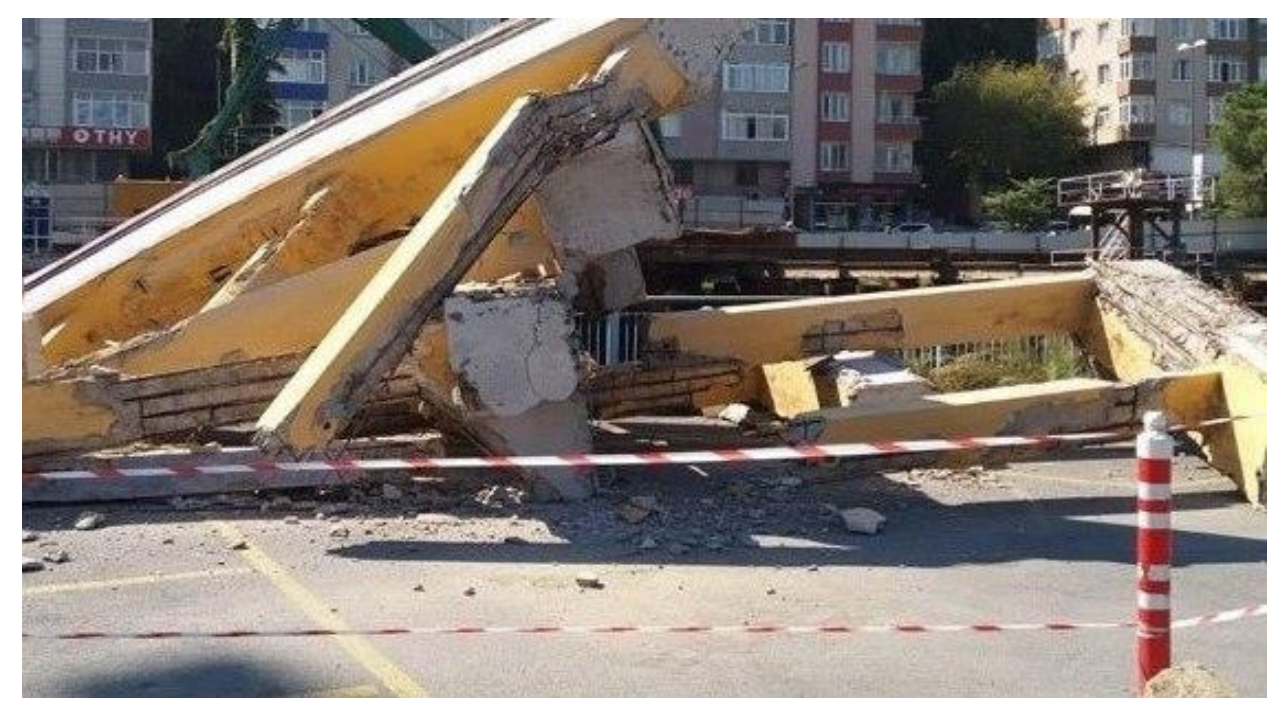

Şekil 18. Köprünün kontrollü bir şekilde yıkılıp kaldırılması (URL-6, 2018)

\section{Sonuçlar}

Bu çalışmada, 1932 yılında İstanbul ili, Eyüpsultan ilçesinde, Alibeyköy Deresi üzerine inşa edilen ve 2018 yılında yol genişletme çalışmaları sebebiyle kontrollü bir şekilde yıkılana kadar 86 yıl boyunca hizmet veren tarihi Fil Köprüsü'nün yapısal ve dinamik özellikleri incelenmiş ve kayıt altına alınmaya çalışılmıştır. Çalışmada elde edilen sonuçlar kısaca şu şekilde özetlenebilir:

- Yerinde alınan ölçümlerle, köprünün rölevesi çıkarılmıştır.

- Yap1 üzerinde alınan Schmidt çekici okumalarının referans alınan bir çalışmada önerilen korrelasyon fonksiyonları yardımıyla analiz edilmesi sonucu beton dayanıminin 6 $\mathrm{MPa}$ ve $15 \mathrm{MPa}$ arasında değiştiği görülmüş, ortalama dayanım $10.75 \mathrm{MPa}$ olarak hesaplanmıştır.

- Köprü elemanları üzerinde donatı tespit cihazı ile incelemeler yapılarak donatı tipi ve sayıları bulunmuştur. Kullanılan donatıların düz (S220a) çubukları olduğu tespit edilmiştir.
- Askı çubuklarının yük taşıma kapasiteleri baz alınarak, köprünün emniyetli bir şekilde taşıyabileceği hareketli yük $16.3 \mathrm{kN} / \mathrm{m}^{2}$ olarak hesaplanmıştır.

- Köprüyü oluşturan kemer yapıda eksen eğrisinin finüküler biçimde tasarlanıp tasarlanmadiğı kontrol edilmiştir. Yapılan analizlerde köprü üzerindeki tüm noktalarda basınç eğrisinin her zaman kesit içinde kaldığ gösterilmiştir.

- Köprü üzerinde askı çubuklarına 4 adet tek eksenli ivme ölçer yerleştirilmiş ve yap1 üzerinde serbest titreşim ölçümleri alınmıştır. Elde edilen titreşim verisi, Artemis Modal programı kullanılarak analiz edilmiş, yapının frekans, sönümleme oranları ve mod şekilleri gibi modal parametreleri hesaplanmıştır.

- Köprünün modellenmesinde kullanılacak olan Elastisite Modülü değerinin Schmidt çekici gibi basit bir malzeme testiyle ne derece doğru hesaplanabileceği sorgulanmıştır. Yapılan incelemelerde özellikle düşük değerlerdeki beton dayanımları için yapısal periyotların Schmidt çekici değerlerine karşı çok yüksek 
bir duyarlı1ığa sahip olmadığı görülmüştür. Elastisite modülünün yanlış hesaplandığ1 durumlarda dayanım hata oranının \%60 mertebesinde olduğu tahminler için bile periyot hata payı en fazla $\% 5$ mertebesindedir.

- Elde edilen bilgiler 1şı̆̆ında köprü, SAP2000 programı kullanılarak modellenmiş, dinamik özellikleri (titreşim periyotları ve mod şekilleri) hesaplanmıştır. Kalibrasyonu yapılan SAP2000 modelinden elde edilen salınım periyotlarıyla titreşim ölçümlerden hesaplanan değerler son derece yakındır. Yapının davranışında belirleyici olan düşük frekanslı modlar için tahmin edilen ve ölçülen değerler arasındaki fark en fazla \%2,4 mertebesindedir. Daha yüksek frekanslı modlar göz önüne alındığında bu oran 5.4 \%'e kadar çıkabilmektedir. Ancak mod sayısı arttıkça incelenen modun yapının dinamik davranışına olan etkisi de azalmaktadır.

\section{Teşekkür}

Yazarlar, köprü üzerinde donat1 tespit çalışmalarında ve titreşim testlerinin gerçekleştirilmesinde yardımlarını esirgemeyen İnş. Yük. Müh. Eren YECAN ve İnş. Yük. Müh. Altuğ PEKER'e teşekkür ederler.

\section{Kaynaklar}

Akbaş, Ş. (2012). Tarihi Yatağan Demirköprü yapısal analiz raporu, Tarihi Yatağan Demirköprü rölöve-restitüsyon-restorasyon projesi: Karayolları Genel Müdürlüğü Arşivi, Ankara.

Bakırtaş, İ. (2013). Tarihi Fil Köprüsü teknik raporu. ITÜ, Tarihi Fil Köprüsü rölöve-restitüsyonrestorasyon projesi. Karayolları Genel Müdürlüğü Arşivi, Ankara.

Bayraktar, A. (2014). Tarihi Birecik Köprüsü yapısal analiz raporu. KTÜ, Tarihi Birecik Köprüsü rölöve-restitüsyon-restorasyon projesi, Karayolları Genel Müdürlüğü Arşivi, Ankara.

Cho, K., Park, Y.H. and Cho, J.R. (2019). Model updating using measurements from sensors installed in arbitrary positions and directions. Applied Sciences (Switzerland), 9(20). doi: 10.3390/app9204309

Forsyth, M. (2007). Structures and construction in historic building conservation: Wiley-Blackwell. ISBN-13: 978-1405111713.

Hester, D., Koo, K., Xu, Y., Brownjohn, J. and Bocian, M. (2019). Boundary condition focused finite element model updating for bridges. Engineering Structures, $198 . \quad$ doi: 10.1016/j.engstruct.2019.109514
İlhan İ. (2000). Beton (Schmidt) çekici ne işe yarar? TMH Türkiye Mühendislik Haberleri Dergisi, 6(410), 27-29.

KGM Karayolları Genel Müdürlüğü (2012). Tarihi Fil (Silahtarăga) Köprüsü ek rapor. Sanat Yapıları Dairesi Başkanlığı, Traihi Yapılar Şube Müdürlüğü, Ankara.

Öngören, C. (2014). Tarihi Çamçavuş Köprüsü yapısal analiz raporu, Tarihi Çamçavuş Köprüsü rölöverestitüsyon-restorasyon projesi: Karayolları Genel Müdürlüğü Arşivi, Ankara.

Sert, H., Partal, E.M., Nas, M., Yılmaz, S., Demirci, H., Avşin, A. and Korkmaz, H.İ. (2015). Restorations of the historical iron/steel bridges. 8th International Symposium on Steel Bridges, Türk Yapısal Çelik Derneği, September 14-16, İstanbul.

Sert, H., Partal, E.M., Nas, M., Yılmaz, S., Demirci, H., Avşin, A. ve Turan G.S. (2015). Tarihi köprülerin restorasyonları kapsamında yürütülen yapısal analiz çalışmaları ve sonuçları. Tarihi Eserlerin Güçlendirilmesi ve Geleceğe Güvenle Devredilmesi Sempozyumu. Ekim 2015, Erzurum, Türkiye.

Şener, S., ve Şener, K.C. (2015). Fil Köprü'nün yapısal özellikleri. Tarihi Eserlerin Güçlendirilmesi ve Geleceğe Güvenle Devredilmesi Sempozyumu. Ekim 2015, Erzurum, Türkiye.

TS 500 (2000) Betonarme yapıların tasarım ve kuralları yönetmeliği. Ankara.

URL-1, http://kopriyet.blogspot.com/2016/06/silahdara ga-koprusu.html. 20 Nisan 2020.

URL-2,https://www.pcb.com/products?model=393b04. 20 Nisan 2020.

URL-3, http://www.tdg.com.tr/tr/urun/8/testbox2010. 20 Nisan 2020.

URL-4,https://svibs.com/wpcontent/uploads/2019/10/Overview_versions.pd f. 20 Nisan 2020.

URL-5, https://www.csiamerica.com/products/sap2000. 20 Nisan 2020.

URL-6, http://www.habereyup.com/eyupsultan-da-birtarih-yok-oluyor_9619.html. 20 Nisan 2020.

Xia, Z., Li, A., Li, J., Shi, H., Duan, M. and Zhou, G. (2020). Model updating of an existing bridge with high-dimensional variables using modified particle swarm optimization and ambient excitation data. Measurement: Journal of the International Measurement Confederation, 159. doi: 10.1016/j.measurement.2020.107754 